\title{
STADES METHOD FOR SURGICAL CORRECTION OF UPPER EYELID TRICHIASIS-ENTROPION: RESULTS AND FOLLOW-UP IN 21 CASES
}

\author{
MÉTODO DE STADES PARA A CORREÇÃO DA TRIQUÍASE-ENTRÓPIO DA PÁLPEBRA \\ SUPERIOR: RESULTADOS E ACOMPANHAMENTO DE 21 CASOS
}

\author{
José Luiz Laus ${ }^{1}$ Felipe António Mendes Vicenti ${ }^{2}$ Aline Adriana Bolzan ${ }^{2}$ \\ Paula Diniz Galera ${ }^{2}$ Rodrigo Cezar Sanches ${ }^{3}$
}

\section{SUMMARY}

Trichiasis is a condition in which lhe cuia and facial hairs grow toward lhe cornea or the conjunctiva. The hairs arising from normal sites are pointed ai an abnormal direction. This condition may be caused by prominent nasal folds, entropion, blepharospasm, slipped facial mask and dermoids. The upper eyelid trichiasis-entropion with lower eyelid entropionectropion frequentiy occurs in oíder English Cocker Spaniels. The ocular signs often are epiphora, blepharospasm, conjunctivitis, keratitis and comeal ulceration. Treatment depenas on the severity ofthe condition and must eliminate the ocular contact by misdirected cuia that irritate the eyeball. This report presents a retrospective study of 21 patients with bilateral diffuise trichiasis (15 English Cocker Spaniels; 2 Basset hounds; l Bloodhound; l Fila Brasileiro and 2 mongrel dogs). The procedure described by Stades was employed $m$ ali cases. Postoperatively, topical chioramphenicol oiniment (qid) was appiied in the conjunctival soe and on the open woundfor 2 weeks. Sutures were removed 10 days after surgery. Correction ofpositioning ofthe upper eyelid was successfúl and its apposition to córnea was normal. In most of the cases the reepithelialiwtion was complete one month after surgery. No signs ofrecurrence werefound and there appeared to be no loss of normal fünction of the eyelid in the 21 dogs available for follow-up examination in a maximum period of 36 months.

Key words: trichiasis, entropion, surgery, Stades.

RESUMO

Triquíase é a condição na qual os cílios e os cabelos faciais crescem em direção à córnea ou conjuntiva. Os pêlos que surgem de locais normais estão apontados em uma direção

\begin{abstract}
anormal. Essa condição pode ser causada por dobras nasais proeminentes, entrópio, blefarospasmo, pele facial redundante e dennóides. A triquíase-entrópio da pálpebra superior associada ao entrópio-ectrópio da pálpebra inferior, frequentemente, ocorre em English Cocker Spaniels idosos. Os sinais oculares são frequentemente epifora, blefarospasmo, conjuntivite, ceratite e ulceração comeana. O tratamento depende da severidade da condição e deve eliminar o contato dos cílios com o globo ocular. Este trabalho apresenta um estudo retrospectivo de 21 pacientes com triquíase difusa bilateral (15 English Cocker Spaniels; 2 Basset hounds; l Bloodhound; l Fila Brasileiro e 2 coes sem raça definida). Empregou-se o procedimento descrito por Stades em todos os casos. No pós-operatório, aplicou-se pomada à base de cloranfenicol (qid) no saco conjuntival e na ferida aberta durante duas semanas. Removeram-se as suturas 10 dias após a cirurgia. Obteve-se êxito na correção do posicionamento da pálpebra superior e observou-se sua justaposição normal em relação à córnea. Ocorreu reepiteliwção completa da ferida um mês após a cirurgia. Não houve sinais de recidiva ou perda da função da pálpebra nos 21 cães avaliados por 36 meses.
\end{abstract}

Palavras-chave: triquíase, entrópio,cirurgia, Stades.

\section{INTRODUCTION}

The outer surface of the upper eyelid margins hás two to four rows of eyelashes directed away from the córnea (SAMUELSON, 1991; SLATTER, 1990; PETERSEN-JONES, 1993). Cilia usually are present on the medial portion and extend across to the lateral canthus (SAMUELSON.1991).

\footnotetext{
${ }^{1}$ Associate Professor, DVM PhD., Ophthalmology Section, Veterinary College, São Paulo State University, Rodovia Carlos Tonanni, km 5, 14870-000, Jaboticabal, SP, Brazil. E-mail: jllaus@ fcav.unesp.br. Author to correspondence.

${ }^{2}$ Graduate Students, Ophthalmology Section, Veterinary College, São Paulo State University.

${ }^{3}$ Undergraduate Student, Ophthalmology Section, Veterinary College, São Paulo State University.
} 
The eyelid margina are hairless and often pigmented (PETERSEN-JONES, 1993). The lower eyelid hás no cilia in the majority of the domestic species (SAMUELSON, 1991; SLATTER, 1990; PETERSEN-JONES, 1993).

Trichiasis is a condition in which the cilia and facial hair contacts the córnea or the conjunctiva. The hairs arising from normal sites are pointed at an abnormal direction. This condition may be caused by prominent nasal folds, entropion, blepharospasm, slipped facial mask and dermoids. The upper eyelid trichiasisentropion with lower eyelid entropion-ectropion frequentiy occurs in oíder English Cocker Spanieis (PETERSEN-JONES, 1993). The ocular signs often are epiphora, blepharospasm, conjunctivitis, keratitis and comeal ulceration (GELATT, 1991; SLATTER, 1990; PETERSEN-JONES, 1993).

Treatment depends on the severity of the condition and must eliminate the ocular contact by misdirected cilia that irritate the eyeball (GELATT, 1991; SLATTER, 1990; PETERSEN-JONES, 1993), including correction of the primary problem, resection of nasal folds, cryoepilation and other methods for removal of the eyelashes (GELATT, 1991; SLATTER, 1990; PETERSEN-JONES, 1993). Some methods of trichiasis repair have disadvantages of complexity, time consumption, less predictable results and recurrences. Lack of optimum surgical correction resulted in development of an enforced secondary granulation method (STADES, 1987). This report presents a retrospective study of 21 patients with bilateral diffuse trichiasis treated with Stades method.

\section{MATERIAL AND METHODS}

The patients were refered to the Ophthalmology Section of Veterinary College of São Paulo State University - UNESP, Jaboticabal SP / Brazil, with a history of lacrimation, ocular irritation and discharge. The patients consisted of 15 English Cocker Spanieis, 2 Basset Hounds, 1 Bloodhound, 1 Fila Brasileiro and 2 mongrel dogs (table 1). Ophthalmic examination revealed epiphora, purulent discharge, blepharospasm, photophobia, conjunctivitis and ocasionally comeal ulceration and edema.

The procedure described by STADES (1987) was employed on ali cases (figures 1, 2, 3 and 4). This method is used for surgical correction of upper eyelid trichiasis-entropion. It consists in removing 15 to $25 \mathrm{~mm}$ of upper eyelid skin. A skin incision is made along the upper eyelid edge, 0.5 to $1.0 \mathrm{~mm}$ dorsally to the meibomian gland openings and inferiorly to the fírst upper eyelid cilia. The incision begins 2 to $4 \mathrm{~mm}$ from the medial canthus and continues 5 to $10 \mathrm{~mm}$ beyond the lateral canthus. The second incision is made in a bow line, approximately following the sulcus parallel to the dorsal orbital rim, which means a maximum of 15 to $25 \mathrm{~mm}$ from the eyelid edge. The circumcised skin is dissected bluntiy with Steven's scissors and cut away dorsally. The wound edge is then cut away at the eyelid margin flatly over the meibomian glands. If the foilicles remain at the lid edge, they are destroyed by cauterization or by scraping with a scalpel blade. The dorsal wound edge is sutured carefúliy to the subcutis, just dorsally to the base of the meibomian glands 5 to $6 \mathrm{~mm}$ from lid margin. Initially, four to fíve simple interrupted marker sutures are placed for positioning. A continuous suture from canthus to canthus is then placed, leaving the rest of the wound open for forced secondary granulation healing and preventing spontaneous wound retraction and wound closure with subsequent recurrence of trichiasis. An absorbable suture material ${ }^{\mathrm{a}}$ is used. Postoperative medication consists of topical choramphenicol

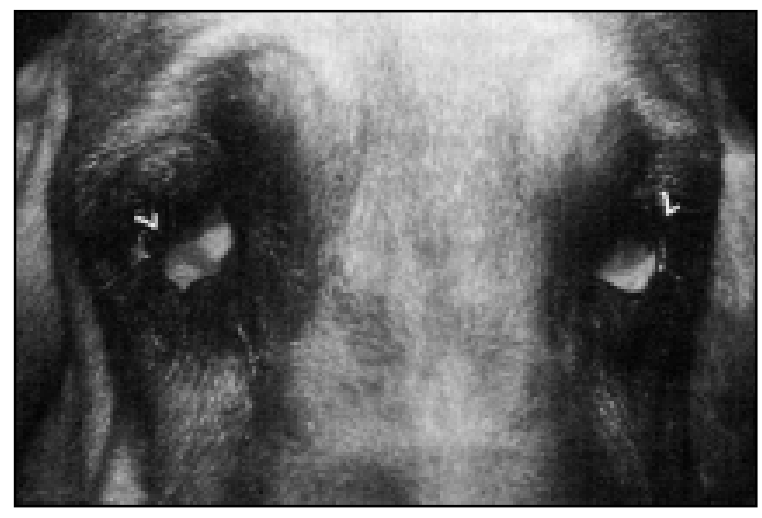

Figure 1 - Bilateral trichiasis - entropion of Bloodhound before surgery. 


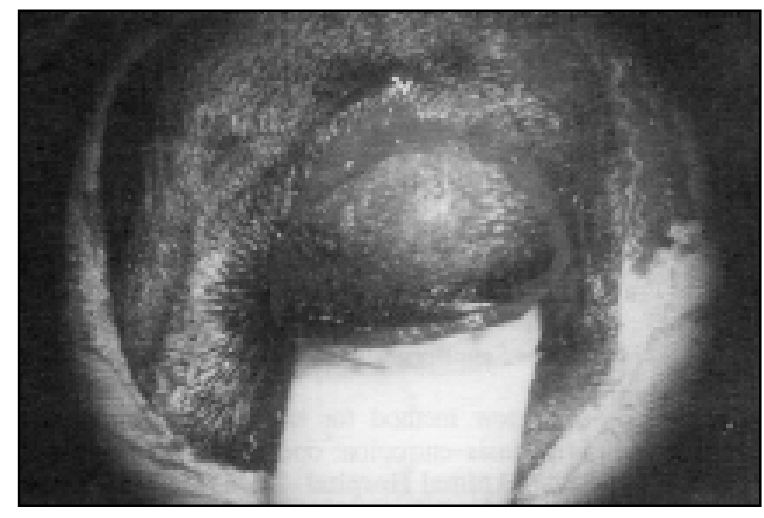

Figure 2 - Initial phase of the surgical procedure. Notice limited areas and cutaneous incision for blepharoplasty.

ointment $^{\mathrm{b}}$ qid in the conjunctival sac and on the open wound for 2 weeks. Sutures are removed 9 to 10 days postoperatively. The remaining wound is allowed to heal by secondary granulation and epithelialization, which gradually will become pigmented. The patients were re-examinated at 7, 15 days and 1, 2, 3, 4, 6, 12 and 36 months postoperatively.

\section{RESULTS AND DISCUSSION}

The technique was $100 \%$ effective, without complications or recurrence. The evertion of the eyelid and a hairless strip of scar tissue adjacent to the eyelid margins prevented the recurrences. Correction of positioning of the upper eyelid was successfui and its apposition to córnea was normal. Some eyelash-like hairs had remained on the eyelid edge in some cases, but they no longer reached the córnea. At removal of sutures on the ninth or tenth day after surgery, all open wounds were fílled by granulation tissue, and reepithelialization had began.

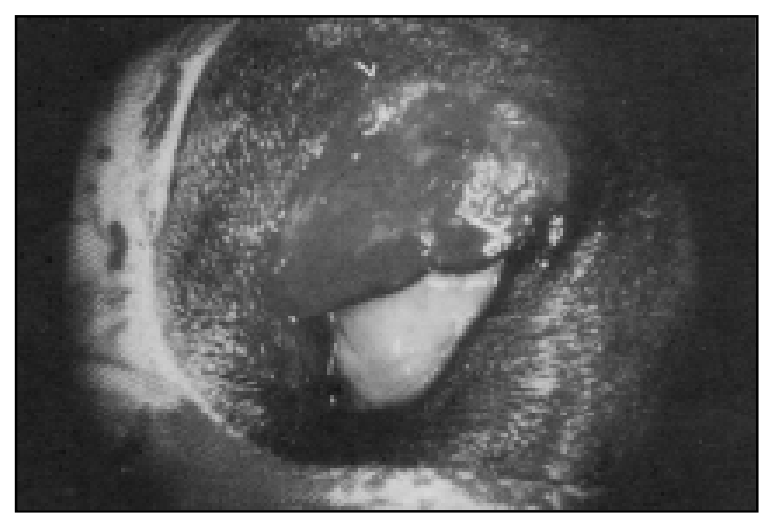

Figure 3 - Intermediary phase of the surgical procedure. Notice palpebral cutaneous area excised.

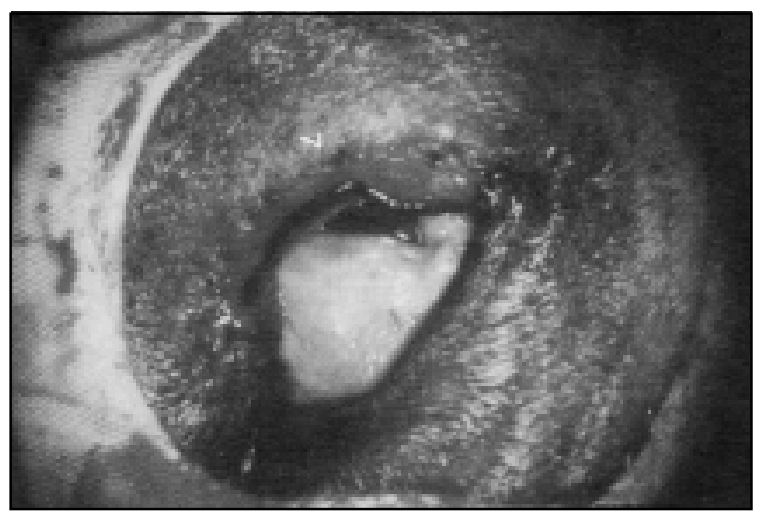

Figure 4 - Final phase of the surgical procedure. Notice sutures and exposed subcutaneous of the palpebral area.

In most of the cases the reepitelialization was complete at one month after surgery. There appeared to be no loss of normal function of the eyelid (figure 5). These results are according to STADES (1987) and STADES \& BOEVE (1987).

Several treatments exist for trichiasis but none is without potential complications such as recurrence within days or weeks and some are time consuming. The success of these methods depends aiso on the aethiology of the disease. Once trichiasis is frequentiy associáted with entropion, some treatments may not be effective in this cases. According to PETERSEN-JONES (1993), upper eyelid trichiasis-entropion occurs most commonly in oíder English Cocker Spaniels. This study confirmed the high prevalence of trichiasis in English Cocker Spaniels. Additional data is given in the Table 1. It was observed frequentiy coexistence of keratoconjunctivitis sicca (KCS) and trichiasisentropion of the upper eyelid, although there is no real relationship between them according to STADES \& BOEVE (1987).

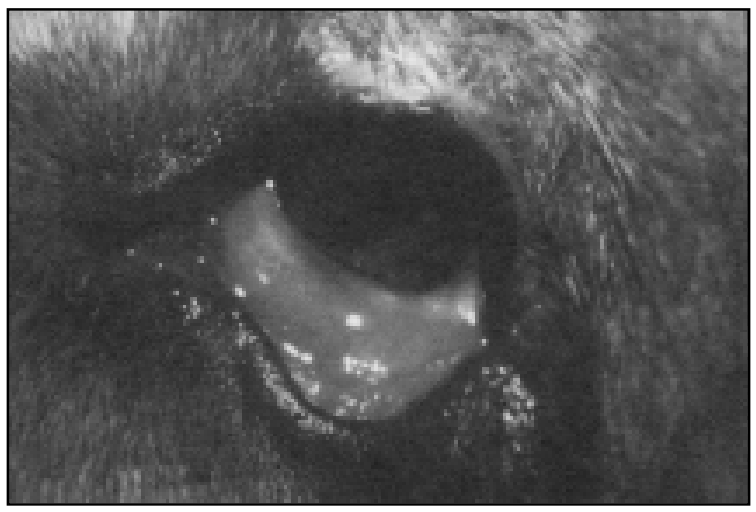

Figure 5 - Aspect of the palpebral condition 1 month after surgery. 


\section{CONCLUSIONS}

The procedure described by STADES (1987) is relatively quick and simple technique. It is important to dissect skin with ali its hair foilicles, or else, it will regrow and may irritate the córnea again. This surgical method prevenis recurrence induced by skin folds, as it may be found in some breeds.

\section{SOURCES AND MANUFACTURES}

a - 4-0 Vicryl - ETHICON.

b - Epitezan "Ocuium" - Frumtost S.A.

\section{REFERENCES}

GELATT, K.N. Veterinary ophthalnwlogy. 2 ed. Philadelphia: Lea \& Febiger, 1991. Cap.6: The canine eyelids: p.256-275.
PETERSEN-JONES, S.M. Conditions of the eyelid and nictitanting membrane. In: PETERSEN-JONES, S.M., CRISPIM, S.M. Manual of small animal ophthalmology. Shurdington : Britisth Small Animal Veterinay Association, 1993. Cap.4. p.65-89.

SAMUELSON, D.A. Ophthalmic embriology and anatomy. In: GELATT, K.N. Veterinary ophthalmology. 2 ed. Philadelphia : Lea $\bullet$ S.Febiger, 1991. Cap.1. p.3-123.

SLATTER, D. Fundamentais of veterinary ophthalniology 2 ed. Philadelphia : Saunders, 1990. Cap.7: Eyelids: p. 147-203.

STADES, P.C. A new method for surgical correction of the upper eyelid trichiasis-entropion: operation method. Journal of the American Animal Hospital Association, v.23, p.603606,1987 .

STADES, F.C., BOEVE M.H. Surgical Correction of upper eyelid trichiasis-entropion: results and follow-up in 55 eyes. Journal of the American Animal Hospital Association, v.23, p.607-700,1987. 